\title{
ENVIRONMENTAL IMPACT ASSESSMENT: A MULTI- LEVEL, MULTI-PARAMETRIC FRAMEWORK FOR COASTAL WATERS
}

\author{
M. LEGA ${ }^{1}$, M. CASAZZA ${ }^{1}$, R. TETA ${ }^{2} \&$ C.J. ZAPPA ${ }^{1},{ }^{3}$ \\ ${ }^{1}$ Department of Engineering, University of Naples "Parthenope", Naples, Italy. \\ ${ }^{2}$ Department of Pharmacy, University of Naples "Federico II", Naples, Italy. \\ ${ }^{3}$ Lamont-Doherty Earth Observatory, Columbia University, Palisades, New York, USA.
}

\begin{abstract}
In any process of Environmental Impact Assessment (EIA) a key role is played by the action of monitoring. Indeed, the acquisition of real field data provides the evidence of the environmental status and identifies hazards and sources of pollution. When environmental pollution is revealed, it is important to identify the source following the source-path-target model. However, when monitoring operations are planned, often the three-dimensional (3D) nature of monitored hotspots is neglected. Instead, information can be gathered through a multi-parametric, multi-level framework, which combines multiple disciplines and generates correlations between several data sets acquired in the analysed scenario. This novel new framework is named $\mathrm{MuM}^{3}$, meaning that the proposed Monitoring (M) is MultiDisciplinary, Multi-level and Multi-parametric (i.e. Mu) and it is developed in all the three dimensions of physical space (the superscript ' 3 '). This paper outlines the implementation of this framework. In particular, monitoring polluted coastal waters refers to one of the critical areas identified by EIA regulations. The framework incorporates different spatial scales of observation (Levels) and the potential sensors that can be used at each Level. A three-step work-flow model describes the raw data acquisition and the transformation and integration of different indicators into useful information for EIA. A schematic flow chart describes the approach to developing multi-level, multi-parameter connections. Extension of this framework can be applied to any EIA, especially in the case of critical areas that are identified by the regulations as: (i) Wetlands, riparian areas, river mouths; (ii) Mountain and forest areas; (iii) Nature reserves and parks; (iv) Densely populated areas; (v) Landscapes and sites of historical, cultural or archaeological significance.

Keywords: coastal waters, EIA, environmental impact assessment, environmental monitoring, environmental pollution, framework, multi-level, multi-parameter, $\mathrm{MuM}^{3}$.
\end{abstract}

\section{INTRODUCTION}

Monitoring constitutes one of the relevant steps of Environmental Impact Assessment (EIA), aimed at assessing 'environmental or socioeconomic variables by the systematic collection of specific data in space and time' [1]. The European Directive 2014/52/EU [2] amending the Directive 2011/92/EU [3], indicates that EIA should identify the impacts on: population and human health; land, soil, water, air and climate; material assets, cultural heritage and the landscape; the interaction among the previously identified factors. In particular, according to the Directive Annexes, emission of pollutants, noise, vibration, light, heat and radiation, the creation of nuisances, and the elimination disposal and recovery of waste should be defined, considering the risks to human health, cultural heritage or the environment. Moreover, a special attention should be paid to coastal zones and the marine environment, as well as densely populated areas.

With this respect, monitoring of surface waters is particularly relevant, due to their high exposition to both natural (e.g. sediment transports, atmospheric deposition, etc.) and anthropogenic (e.g. wastewaters release, leachate contamination, artificial modification of natural water flows, etc.) influences [4]-[6]. However, the lack of data often constitutes a barrier to estimate the cumulative effects of those impacts [7]. Moreover, it creates difficulties in identifying the real pollutants sources, which are often far from the place where impacts are revealed [8]. 
With respect to coastal waters, pollution phenomena are often revealed indirectly. This is why several recent publications suggest the use of specific bioindicators, such as mussels, diatoms and cyanobacteria for such a purpose [9]-[15]. Often, detailed analyses revealed both the presence of high concentrations of organic nutrients or a combination of high inorganic nutrients concentrations with low concentrations of dissolved oxygen [16]-[18] also generated by groundwater and direct human waste discharges [20]-[21]. However, without site-specific analyses, aimed at identifying pollution sources, transport and fate (i.e. target), no remediation action can be developed. In the next section, a new framework is described to improve the effectiveness of environmental impact assessment.

\section{MUM $^{3}$ FRAMEWORK}

Here, a multi-disciplinary, multi-scale and multi-parametric framework is outlined, which generates connections among several data sets, to address environmental impact assessment. This novel new framework is called $\mathrm{MuM}^{3}$, as abbreviated form of 'Multi-disciplinary, multiscale and multi-parametric Monitoring'. The number 3, used in $\mathrm{MuM}^{3}$, represents the fact that monitoring occurs in the three-dimensional physical space.

What drives the assessment? The top level is remotely sensed data that needs to be validated by in situ measurements. The surface level is typically a survey of what can and what needs to be done.

\subsection{Infrastructure of the framework}

The core structure of the framework is multi-level that is defined by the platform at each level. Data is acquired using sensors on different platforms that inherently define a spatial scale depending on the altitude of the measurement. The levels are: satellite, aircraft, helicopter, UAV, and surface (e.g. ship, mobile lab, tower). There is the potential for multiple sensors at each level. Some examples are: visible near infrared (VNIR) and thermal infrared (TIR) imaging on satellites, aircraft, helicopters, UAV and at the surface; atmospheric sampling from aircraft, helicopters, UAV and at the surface; physical, chemical, and biological analyses, etc. at the surface and in fast response in the mobile lab. This view of the framework is shown in Fig. 1 and the spatial scales are outlined in Table 1. Spatial scales for each level

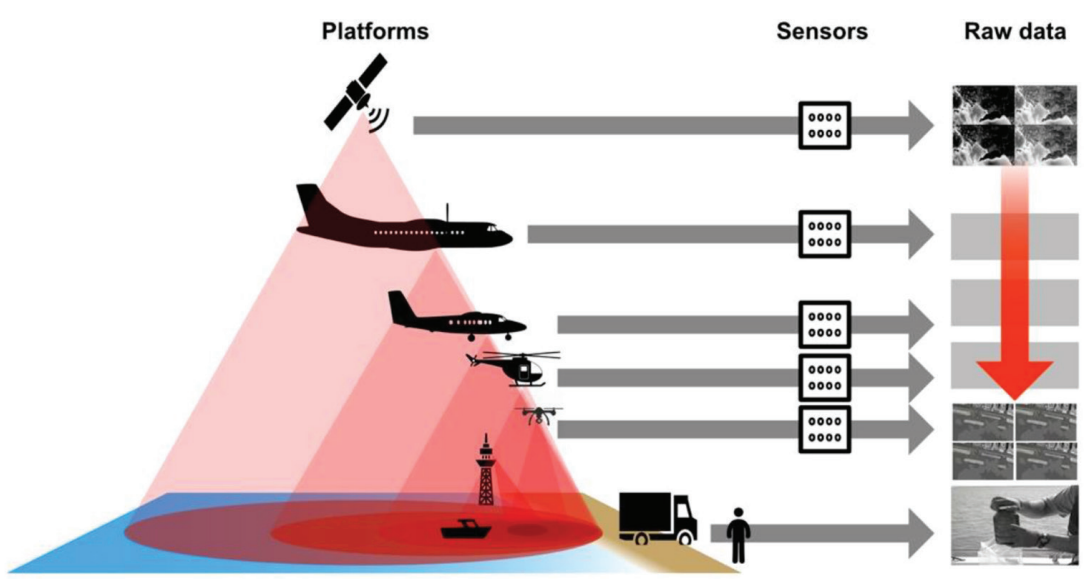

Figure 1: Hierarchical monitoring - Levels/Platforms, sensor, and raw data. 
Table 1: Levels, reference altitude, sensors, sensors resolution, sensors swath, path length/ duration. Note that these are the possible ranges for each specification that can be applied generally to coastal water monitoring. Here, only Small UAVs are described specifically according to the DoD standard classification. Additional UAV categories cover a broad range of size, normal operating altitude, and gross takeoff weight.

\begin{tabular}{|c|c|c|c|c|c|}
\hline Level & Altitude & Sensor & $\begin{array}{l}\text { Sensor } \\
\text { resolution }\end{array}$ & Swath & $\begin{array}{l}\text { Path length/ } \\
\text { duration }\end{array}$ \\
\hline $\begin{array}{l}\text { Satellite (e.g. } \\
\text { Aqua, Terra, } \\
\text { Landsat, } \\
\text { Sentinel) }\end{array}$ & $\begin{array}{l}705 \mathrm{~km} \\
-713 \mathrm{~km}\end{array}$ & $\begin{array}{l}\text { VNIR, TIR, } \\
\text { microwave }\end{array}$ & $15 \mathrm{~m}-1 \mathrm{~km}$ & $\begin{array}{l}100 \mathrm{~km}-1000 \mathrm{~km} \\
\text { (cross track) by } \\
10 \mathrm{~km} \text { (along } \\
\text { track at nadir) }\end{array}$ & $\begin{array}{l}\text { Complete } \\
\text { Earth } \\
\text { coverage: } \\
12-16 \text { days }\end{array}$ \\
\hline Airplane & $\begin{array}{l}1 \mathrm{~km}-10 \\
\mathrm{~km}\end{array}$ & $\begin{array}{l}\text { VNIR, TIR, } \\
\text { microwave, } \\
\text { atmospheric }\end{array}$ & $0.1 \mathrm{~m}-100 \mathrm{~m}$ & $100 \mathrm{~m}-1 \mathrm{~km}$ & $2-15$ hours \\
\hline Helicopter & $\begin{array}{l}0.1 \mathrm{~km}-6 \\
\mathrm{~km}\end{array}$ & $\begin{array}{l}\text { VNIR, TIR, } \\
\text { microwave, } \\
\text { atmospheric }\end{array}$ & $0.1 \mathrm{~m}-10 \mathrm{~m}$ & $100 \mathrm{~m}-1 \mathrm{~km}$ & $1-3$ hours \\
\hline Small UAV & $1 \mathrm{~m}-500 \mathrm{~m}$ & $\begin{array}{l}\text { VNIR, TIR, } \\
\text { meteorologi- } \\
\text { cal }\end{array}$ & $0.01 \mathrm{~m}-1 \mathrm{~m}$ & $1 \mathrm{~m}-100 \mathrm{~m}$ & $\begin{array}{l}30 \text { min-2 } \\
\text { hours }\end{array}$ \\
\hline $\begin{array}{l}\text { Surface (e.g. } \\
\text { boat, tower, } \\
\text { mobile lab) }\end{array}$ & $\begin{array}{l}0 \mathrm{~km}-0.01 \\
\mathrm{~km}\end{array}$ & $\begin{array}{l}\text { VNIR, TIR, } \\
\text { microwave, } \\
\text { meteoro- } \\
\text { logical, water } \\
\text { quality, etc. }\end{array}$ & 1 to $10 \mathrm{~cm}$ & $\begin{array}{l}\text { From point to area, } \\
\text { depending on sen- } \\
\text { sor FOV/resolution }\end{array}$ & \\
\hline
\end{tabular}

are three-fold: sensor resolution, swath extent, and path reach. For example, the satellite sensor resolution ranges from 10's of meters to kilometers, the swath extent is up to 100's to 1000 's of kilometers, with a path that covers globally every 1-16 days.

\subsection{Data processing}

Processing of the raw input data for each sensor that is transformed into information at an intermediate step to generate output products and indicators for all levels/scales. For instance, the MODIS sensor on the Aqua/Terra satellite is used to generate chlorophyll-a maps using a multi-band visible spectrum reflectance algorithm. This is shown in Fig. 2.

\subsection{Multi-level Multi-parameter connections}

Determine connections of this information between levels (or scale) for environmental impact assessment. The goal is to examine components and their interactions between large, and small scales and refine these connections. For example, a region of high chlorophyll-a is detected using satellite data and observe the existence of cyanobacteria at the same location sampled in situ and analyzed in the mobile lab. Remote sensing data/information can be 

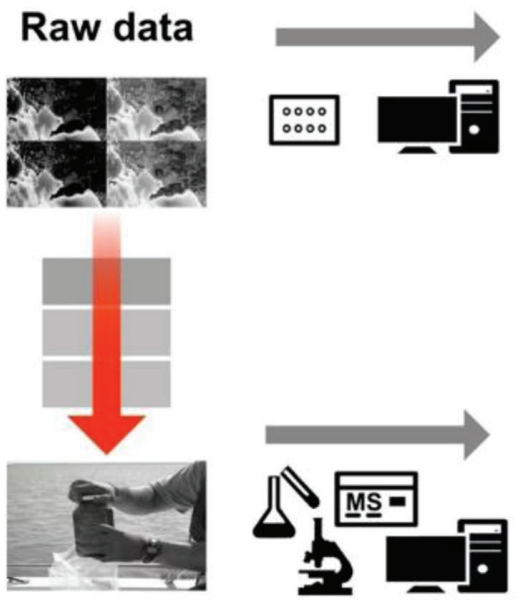

\section{Information}
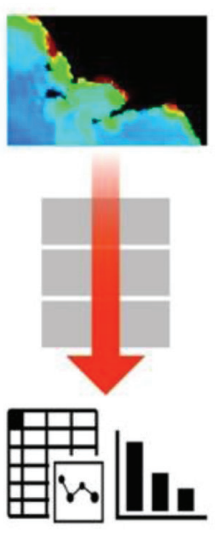

Figure 2: Data processing and reduction from raw data.

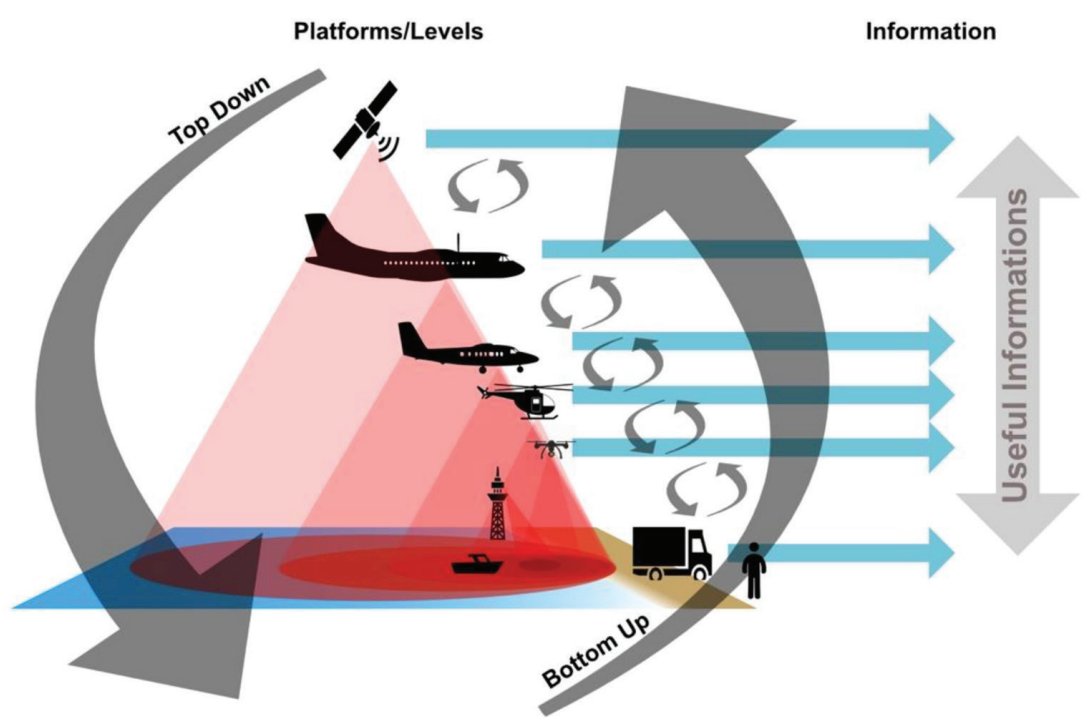

Figure 3: Schematic flow chart that describes the approach to developing multi-level, multiparameter connections.

strategically combined with other data layers in geographic information systems (GIS) [22], creating a unique virtual environment that makes the assessment easier. Figure 3 shows a schematic of the Flow chart that describes the approach to developing these multi-level, multi-parameter connections.

\section{FRAMEWORK IMPLEMENTATION}

The key point is to identify the location and time to define the starting point. This can be done from either a Bottom-Up or Top-Down approach. For instance, in the Bottom-Up 
approach as shown in Fig. 4, the governing body identified pollution target and requests an environmental impact assessment. One, therefore, begins at the surface level and scale up to determine the extent of as well as the source of the pollution. On the other hand, the TopDown approach as shown in Fig. 5 the governing body requests to know if any and where the problem exists. The Top-Down approach would help to determine if there is any pollution without any prior knowledge. Using the satellite data products, hotspots or anomalies for indicators of pollution would target regions to sample in situ for actual existence of pollution. However, the implementation of the Framework can begin at any level/scale, from satellite to in situ, to characterize the environmental complexities at each scale. Finally, as shown in Fig. 6, one iterates between levels to: (i) determine, refine and optimize interconnections and (ii) come to an understanding of what levels and products are most important to the particular problem.

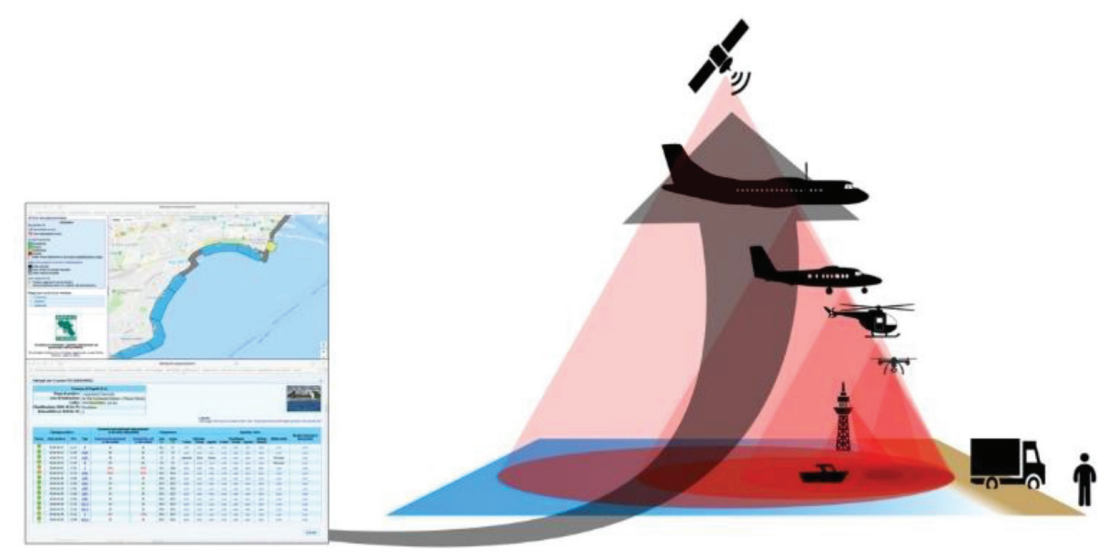

Figure 4: Framework implementation from the bottom up. EPA provides the problem.

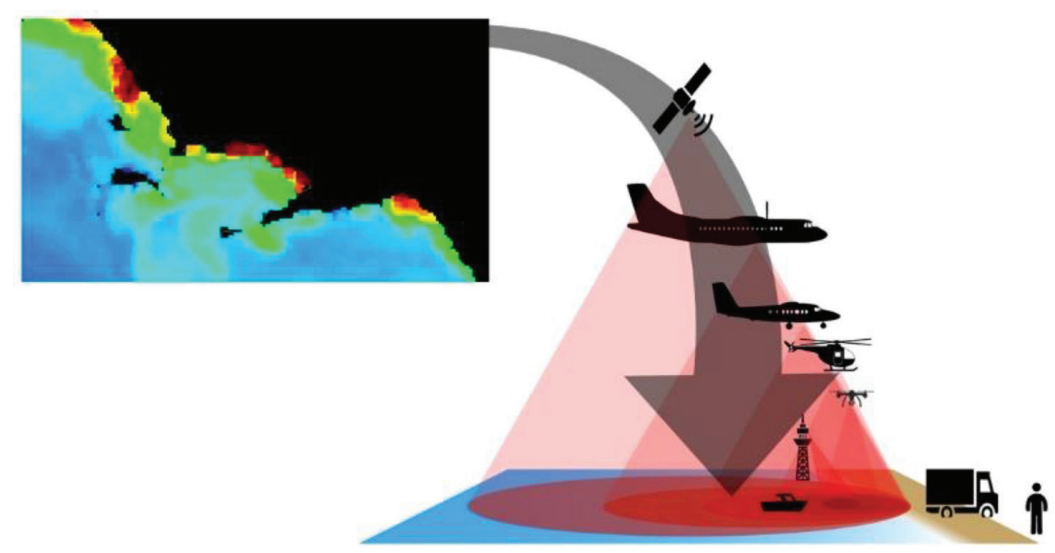

Figure 5: Framework implementation from the top down. EPA asks where the problem exists. 


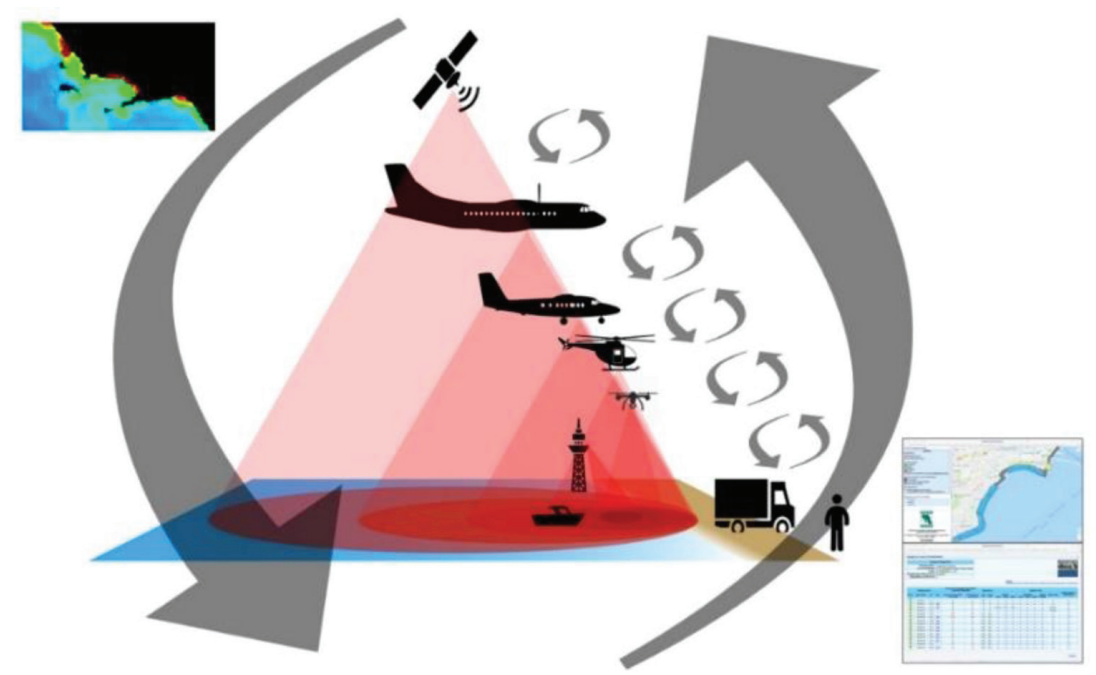

Figure 6: Framework implementation connectivity between levels.

\section{CONCLUDING REMARKS}

This new novel framework can be applied to all phases of environmental impact assessment, including scoping, baseline data collection, impact assessment, and mitigation. Several sensors can be used for such a purpose, as reported by the literature (e.g. [23]-[25]). Besides coastal areas, this framework can be applied to other critical locations, identified by the international Environmental Impact Assessment regulations, such as: (i) Wetlands, riparian areas, river mouths; (ii) Mountain and forest areas; (iii) Nature reserves and parks; (iv) Densely populated areas; (v) Landscapes and sites of historical, cultural or archaeological significance. $\mathrm{MuM}^{3}$ framework application can integrate the process of raw data transformation into information through environmental accounting techniques, as recently discussed by Liu et al. [26]. The same framework can be extended to gather the necessary data for defining the effects of extended and multi-scale pollution episodes [27]-[29], as well as for ecological security [30] and sustainability assessment [31] purposes.

\section{ACKNOWLEDGEMENT}

The data presented in this work derive from the project 'Attività pilota di Monitoraggio di Cianobatteri nella fascia costiera della regione Campania', funded by the 'Centro di Riferimento Regionale per la Sicurezza Sanitaria del Pescato ( CRiSSaP)' and performed in cooperation with the Agency for the Environmental Protection of Campania region in Italy (ARPAC), Istituto Zooprofilattico Sperimentale del Mezzogiorno/Osservatorio Regionale per la Sicurezza Alimentare - IZSM/ORSA, University of Naples "Federico II" (Department of Pharmacy, ref. prof. V. Costantino and Department of Veterinary Medicine and Animal Production, ref. prof. A. Anastasio), University of Naples "Parthenope" (Department of Engineering, ref. prof. M. Lega). This project was supported in part by the University of Naples "Parthenope" (Italy) under 'Bando di sostegno alla ricerca individuale'. This is Lamont-Doherty Earth Observatory contribution number 8239. Finally, the authors are grateful for the support from the United States and Italy Fulbright Commission, who have facilitated this collaboration. 


\section{REFERENCES}

[1] Morris, P. \& Therivel, R. (eds), Methods of Environmental Impact Assessment. Spon Press: London and New York, 2001.

[2] Directive 2014/52/EU of The European Parliament and of the Council of 16 April 2014 amending Directive 2011/92/EU on the assessment of the effects of certain public and private projects on the environment. Online. eur-lex.europa.eu/legal-content/EN/TXT/ PDF/?uri=CELEX:32014L0052\&from=EN (accessed on 10 June, 2018).

[3] Directive 2011/92/EU of The European Parliament and of the Council of 13 December 2011 on the assessment of the effects of certain public and private projects on the environment. Online. eur-lex.europa.eu/legal-content/EN/TXT/PDF/?uri=CELEX:32011L 0092\&from $=\mathrm{EN}$ (accessed on 10 June, 2018).

[4] Jabeen, S., Shah, M.T., Ahmed, I., Khan, S. \& Hayat, M.Q., Physico-chemical parameters of surface and ground water and their environmental impact assessment in the Haripur Basin, Pakistan. Journal of Geochemical Exploration, 138, pp. 1-7, 2014. https://doi.org/10.1016/j.gexplo.2013.12.004

[5] Petrie, J., Diplas, P., Gutierrez, M. \& Nam, S., Characterizing the mean flow field in rivers for resource and environmental impact assessments of hydrokinetic energy generation sites. Renewable Energy, 69, pp. 393-401, 2014. https://doi.org/10.1016/j.renene.2014.03.064

[6] Casazza, M., Maraga, F., Liu, G., Lega, M., Turconi, L. \& Ulgiati, S., River water quality and its relation with air quality: a long-term case study in a remote and pristine NW Italian headwater catchment. Journal of Environmental Accounting and Management, 5(1), pp. 35-47, 2017. https://doi.org/10.5890/jeam.2017.03.004

[7] Jones, F.C., Cumulative effects assessment: theoretical underpinnings and big problems. Environmental Reviews, 24(2), pp. 187-204, 2016. https://doi.org/10.1139/er-2015-0073

[8] Li, H., Yang, Z., Liu, G., Casazza, M. \& Yin, X., Analyzing virtual water pollution transfer embodied in economic activities based on Gray Water Footprint: a case study. Journal of Cleaner Production, 161, pp. 1064-1073, 2017. https://doi.org/10.1016/j.jclepro.2017.05.155

[9] Semary, E. \& Adel, N., Diatoms as bioindicators of littoral zone: a case study. Bangladesh Journal of Botany, 45(5), pp. 1113-1121, 2016.

[10] Teta, R., Della Sala, G., Mangoni, A., Lega, M. \& Costantino, V., Tracing cyanobacterial blooms to assess the impact of wastewaters discharges on coastal areas and lakes. International Journal of Sustainable Development and Planning, 11(5), pp. 804-811, 2016. https://doi.org/10.2495/sdp-v11-n5-804-811

[11] Beyer, J., Green, N.W., Brooks, S., Allan, I.J., Ruus, A., Gomes, T., Bråte, I.L.N. \& Schøyen, M., Blue mussels (Mytilus edulis spp.) as sentinel organisms in coastal pollution monitoring: a review. Marine Environmental Research, 130, pp. 338-365, 2017. https://doi.org/10.1016/j.marenvres.2017.07.024

[12] Narale, D.D. \& Anil, A.C., Spatial distribution of dinoflagellates from the tropical coastal waters of the South Andaman, India: Implications for coastal pollution monitoring. Marine Pollution Bulletin, 115(1-2), pp. 498-506, 2017. https://doi.org/10.1016/j.marpolbul.2016.11.035

[13] Teta, R., Romano, V., Della Sala, G., Picchio, S., De Sterlich, C., Mangoni, A., Di Tullio, G., Costantino, V. \& Lega, M., Cyanobacteria as indicators of water quality in Campania coasts, Italy: a monitoring strategy combining remote/proximal 
sensing and in situ data. Environmental Research Letters, 12(2), p. 024001, 2017. https://doi.org/10.1088/1748-9326/aa5649

[14] Teta, R., Esposito, G., Casazza, M., Zappa, C.J., Endreny, T., Mangoni, A., Costantino, V. \& Lega, M., Bioindicators as a tool in environmental impact assessment: cyanobacteria as a sentinel of pollution. International Journal of Sustainable Development and Planning, In press.

[15] Teta, R., Della Sala, G., Glukhov, E., Gerwick, L., Gerwick, W.H., Mangoni, A. \& Costantino, V., Combined LC-MS/MS and molecular networking approach reveals new Cyanotoxins from the 2014 Cyanobacterial bloom in Green Lake, Seattle. Environmental Science and Technology, 49(24), pp. 14301-14310, 2015. https://doi.org/10.1021/acs.est.5b04415

[16] Al-Azri, A.R., Piontkovski, S.A., Al-Hashmi, K.A., Goes, J.I., Gomes, H.D.R. \& Glibert, P.M., Mesoscale and nutrient conditions associated with the massive 2008 Cochlodinium polykrikoides bloom in the Sea of Oman/Arabian Gulf. Estuaries and Coasts, 37(2), pp. 325-338, 2014. https://doi.org/10.1007/s12237-013-9693-1

[17] Pati, S., Dash, M.K., Mukherjee, C.K., Dash, B. \& Pokhrel, S., Assessment of water quality using multivariate statistical techniques in the coastal region of Visakhapatnam, India. Environmental Monitoring and Assessment, 186(10), pp. 6385-6402, 2014. https://doi.org/10.1007/s10661-014-3862-y

[18] Saab, M.A.A. \& Hassoun, A.E.R., Effects of organic pollution on environmental conditions and the phytoplankton community in the central Lebanese coastal waters with special attention to toxic algae. Regional Studies in Marine Science, 10, pp. 38-51, 2017. https://doi.org/10.1016/j.rsma.2017.01.003

[19] Shaik, A.U.R., Biswas, H., Babu, N.S., Reddy, N.P.C. \& Ansari, Z.A., Investigating the impacts of treated effluent discharge on coastal water health (Visakhapatnam, SW coast of Bay of Bengal, India). Environmental Monitoring and Assessment, 189(12), pp. 643-658, 2017. https://doi.org/10.1007/s10661-017-6344-1

[20] Tedd, K.M., Coxon, C.E., Misstear, B.D.R., Daly, D., Craig, M., Mannix, A. \& Williams, N.H., An integrated pressure and pathway approach to the spatial analysis of groundwater nitrate: A case study from the southeast of Ireland. Science of the Total Environment, 476, pp. 460-476, 2014. https://doi.org/10.1016/j.scitotenv.2013.12.085

[21] Amin, M.N., Kroeze, C. \& Strokal, M., Human waste: An underestimated source of nutrient pollution in coastal seas of Bangladesh, India and Pakistan. Marine Pollution Bulletin, 118(1-2), pp. 131-140, 2017. https://doi.org/10.1016/j.marpolbul.2017.02.045

[22] Lega, M. \& Persechino, G., GIS and infrared aerial view: Advanced tools for the early detection of environmental violations. WIT Transactions on Ecology and the Environment, 180, pp. 225-235, 2014. https://doi.org/10.2495/wm140191

[23] Gargiulo, F., Persechino, G., Lega, M. \& Errico, A., IDES project: a new effective tool for safety and security in the environment. International Conference on Algorithms and Architectures for Parallel Processing, Springer, Cham, pp. 201-208, 2013.

[24] Errico, A., Angelino, C.V., Cicala, L., Persechino, G., Ferrara, C., Lega, M., Vallario, A., Parente, C., Masi, G., Gaetano, R., Scarpa, G., Amitrano, D., Giuseppe Ruello, G., Verdoliva, L. \& Poggi, G., Detection of environmental hazards through the feature-based fusion of optical and SAR data: a case study in southern Italy. International Journal of Remote Sensing, 36(13), pp. 3345-3367, 2015. https://doi.org/10.1080/01431161.2015.1054960 
[25] Errico, A., Angelino, C.V., Cicala, L., Podobinski, D.P., Persechino, G., Ferrara, C., Lega, M., Vallario, A., Parente, C., Masi, G., Gaetano, R., Scarpa, G., Amitrano, D., Ruello, G., Verdoliva, L. \& Poggi, G., SAR/multispectral image fusion for the detection of environmental hazards with a GIS. In Proceedings of SPIE. The International Society for Optical Engineering, 2014. https://doi.org/10.1117/12.2066476

[26] Liu, G., Yin, X., Pengue, W., Benetto, E., Huisingh, D., Schnitzer, H., Wang, Y. \& Casazza, M., Environmental accounting: In between raw data and information use for management practices. Journal of Cleaner Production, 197(1), pp. 1056-1068, 2018.

[27] Lega, M. \& Endreny, T., Quantifying the environmental impact of pollutant plumes from coastal rivers with remote sensing and river basin modelling. International Journal of Sustainable Development and Planning, 11(5), pp. 651-662, 2016. https://doi.org/10.2495/sdp-v11-n5-651-662

[28] Ferrara, C., Lega, M., Fusco, G., Bishop, P. \& Endreny, T., Characterization of terrestrial discharges into coastal waters with thermal imagery from a hierarchical monitoring program. Water, 9(7), p. 500, 2017. https://doi.org/10.3390/w9070500

[29] Casazza, M., Lega, M., Liu, G., Ulgiati, S. \& Endreny, T.A., Aerosol pollution, including eroded soils, intensifies cloud growth, precipitation, and soil erosion: a review. Journal of Cleaner Production, 189, pp. 135-144, 2018. https://doi.org/10.1016/j.jclepro.2018.04.004

[30] Yang, Q., Liu, G., Hao, Y., Coscieme, L., Zhang, J., Jiang, N., Casazza, M. \& Giannetti, B.F., Quantitative analysis of the dynamic changes of ecological security in the provinces of China through emergy-ecological footprint hybrid indicators. Journal of Cleaner Production, 184, pp. 678-695, 2018. https://doi.org/10.1016/j.jclepro.2018.02.271

[31] Liu, G., Brown, M.T. \& Casazza, M., Enhancing the sustainability narrative through a deeper understanding of sustainable development indicators. Sustainability, 9(6), p. 1078, 2017. https://doi.org/10.3390/su9061078 